\title{
Landslides susceptibility mapping at Gunung Ciremai National Park
}

\author{
Faizin $^{1}$, Bambang Azis Nur ${ }^{2}$ \\ ${ }^{1}$ Master Program in Environmental Science, Diponegoro University, Semarang - Indonesia \\ ${ }^{2}$ Faculty of Marine and Fisheries, Diponegoro University, Semarang - Indonesia
}

\begin{abstract}
In addition to agriculture, tourism became one of primary economic income for communities around Mount Ciremai, West, Java. Unfortunately, the landscape of West Java has many potential causes to disasters, mainly landslides. Mapping of disaster susceptibility area is needed as a consideration of tourism planning. The study was conducted in Gunung Ciremai National Park, West Java. This paper propose a methodology to map landslides susceptibilities based on spatial data. Using Geographic Information System tools, several environmental parameters such as slope, land use, elevation, and lithology are scored to build a landslide susceptibility map. Then, susceptibility map is overlaid with Utilization Zone.
\end{abstract}

\section{Background}

As declared by Minister of Tourism, Dr. Ir. Arief Yahya, M.Sc, tourisms a main contributor to Indonesia GDP, devisa resource and provide easiest and cheapest occupations [1]. Tourism proved can support the economic growth and activities of the community [2].

The change of tourism trends from conventional (mass tourism) to alternative tourism encourages the creation of a tourism product based on natural resources and managed by conservation principles as known as ecotourism $[3,4]$.

Indonesia has a lot of natural beauty, so that the beauty of nature becomes one of the main stay of Indonesian tourism. Unfortunately, Indonesia's geographical conditions provide great opportunities for natural disasters, such as volcanic eruptions, landslides and floods. So the tourism area is also not separated from the disaster aspect.

Not all disasters will bad affect tourism activities. Even an active volcano can be developed for tourism [5]. Yogyakarta has developed a lava tour that utilizes this disaster phenomenon.

Landslides (landslides) associated with the soil mass motion caused by gravity [6]. Landslide is one of the most devastating natural disasters [7]. In Indonesia, West Java is the province with the most landslide events [6]. Many factor triggering landslides. Usually landslides occur in areas with steep slopes. Areas that fall into the landslide zone are generally located in areas of corrugated hills and steep hills [8]. In various models of erosion and landslide determination, slope factors are included in the main elements [9].

Rain fall is one of the major climatic elements that role against landslide and erosion events [10]. The rain has the potential to cause an avalanche depending on the intensity and duration. Raindrops destroy the soil aggregates and cause landslides. The rain water infiltrated into the soil pores that escaped the water softens the soil so that the soil loses its carrying capacity of the slope.

Geological factors affect the landslide potential based on the arrangement and lithology of rocks. Rock properties are determined by the origin of rocks and mineral composition that affect the sensitivity to erosion and landslides. In mountainous areas, soil materials dominated by solid rocks from volcanic, sedimentary, and metamorphic rocks. Soils formed from sedimentary rocks, especially clay, calcareous limestone or marl and limestone, are relatively sensitive to erosion and landslides. Volcanic rocks are generally resistant to erosion and landslides. The scoring of geological factors is distinguished by a geological arrangement or consisting of one or more textural properties.

The land cover contributed to the landslide. Low land cover is suspected as one of the factors that cause landslide prone [11]. Buchori asserted that land cover is influenced by human intervention factor in fulfilling the necessities of life [10].

Landslide vulnerability can be interpreted as landslides possibilities to occur in an area based on local terrain conditions [12], vulnerability maps are usually obtained by cartography [13]. This thermal so describes the speed and intensity of landslides that have occurred or potentially occur. But the map of vulnerability does not consider the aspect of time [12].

Researchers try to understand the phenomenon of landslide disaster as a stub for mitigation, minimize the casualties and losses from the impact [14]. The assessment of landslide vulnerability is also required in regional development considerations. The assessment of landslide vulnerability can be considered as a first step for hazard management and landslide risk [15]. 
From several methods of landslide vulnerability assessment, broadly classified into two namely quantitative and qualitative. Qualitative methods depend on expert opinion $[13,16,17]$. Sabokbar declare there are three method, quantitative, qualitative and hybrid [18]. Medium quantitative methods have less dependence on human opinion (experts).

\section{Methodology}

The research was held in July 2017 laboratory of computation, Diponegoro University. Mapping of landslide susceptibility in this study use quantitative method which the proposed by Wati with a slight modification [19]. The data were collected by literature study, mainly from official maps, field observation, documentation and study of literature related to the research topic.

The creation of landslides susceptibility map was built by simple overlay with weighted scores. The determination of score and weighting is based on literature study. The score range is $1-4$, which the higher score mean higher effect on the landslide event. In operation, the making susceptibility class is technically done with the ArcGis 10.3 tools.

Four of the five parameters are used in susceptibility analysis, i.e. slopes, lithology, soil type, and land use. Rainfall parameters are not included in the calculations because the rainfalls in TNGC area are relatively same. Determination of weights and scores of each parameter as in table 2 using the following assumptions:

1. slope; slope to an related with Voltage sliding more high. Meaning increasingly big slope, the possibility damage more Great.

2. Lithology; Volcanic generally more solid and persistent more persistent with erosion.

3. Soil types; soil have each texture and permeability. Soil with soft texture keep water and release it more slowly release so that more susceptible on landslides. Low permeability increasing high possibility landslides occurrences.

4. Land use. Land use not directly indicator of vulnerability, but densely of vegetation can increasing the mass of soil. Paddy field with it terrace plantation reducing possibility of landslides.

Table 1 Weights and scores of each parameter

\begin{tabular}{|l|c|}
\hline Parameters and weighted factors & Score \\
\hline Slope (weight: 40.8) & \\
\hline Flat and undulating (0- 8\%) & 1 \\
\hline Moderately sloping (8-15\%) & 2 \\
\hline Hilly and moderately steep (15-45\%) & 3 \\
\hline Steep (> 45\%) & 4 \\
\hline Lithology (weight: 24.2$)$ & \\
\hline Andesite & 1 \\
\hline
\end{tabular}

\begin{tabular}{|l|c|}
\hline Parameters and weighted factors & Score \\
\hline Lava rock & 2 \\
\hline Breccia & 3 \\
\hline volcanic rock & 4 \\
\hline The soil type (weight: 19.2) & \\
\hline Alluvial, & 1 \\
\hline Andosol, latosol & 2 \\
\hline Regosol, Litosol & 3 \\
\hline Brown forestsoil & 4 \\
\hline Land use (weight: 15.8) & \\
\hline $\begin{array}{l}\text { Area limestone, wetland, paddy field, pine } \\
\text { plantation }\end{array}$ & 1 \\
\hline Shrubs and bush, mixed garden, forests & 2 \\
\hline Mixed paddy fields and vegetable garden & 3 \\
\hline $\begin{array}{l}\text { Settlement, vegetable garden, sparse } \\
\text { vegetation in forest region }\end{array}$ & 4 \\
\hline
\end{tabular}

Source: Wati [19], with modification

Classes of vulnerability are classified into five levels i.e. very low, low, medium, high and very high based on the accumulation of weighted scores. The class of was done by natural break classification.

\section{Result ad Discussion}

Landslides Susceptibility Map (LSM) built based on four parameters, i.e. slope, lithology, soil type, and land use. Each parameter is represent by map. Slope (peta kelerengan), lithology (litologi), Soil type (jenis tanah) land use (penutupan lahan) are obtained from RBI countur map, geological map, soil map and RBI map, respectively. Each map is clipped by border map of TNGC. After each map is weighted on each field attribute, then it is over laid by union fiture on ArcGIS. Then, susceptibility map is over laid with zonation map on TNGC.

Land slide susceptibility in this research is categorized in to five classes utilizing natural break classification based on accumulative weight and score.

\subsection{Slope}

Slope map obtained from Digital Elevation Model (DEM) is processed from SRTM imagery at Kuningan Regency, which downloaded from earth explorer.usgs.glovis. The resulted slope map is raster data. Through field calculator in ArcGIS, the score of 1, 2, 3 and 4 area are 1872,2739, 4109, $86 \mathrm{Ha}$, respectively

\subsection{Lithology}

The lithology here refers to the formation of the soil-forming rock obtained from the Geological map of the system, Djawasheet Ardjawinangun sheet 1309-01 from the Directorate of Geology. The resulting geologic maPpis raster. Through field calculator obtained area with a score of 1 is $1880 \mathrm{Ha}$, score 2 is $3200 \mathrm{Ha}$, score 3 is $9 \mathrm{Ha}$ and score 4 is $3689 \mathrm{Ha}$. 


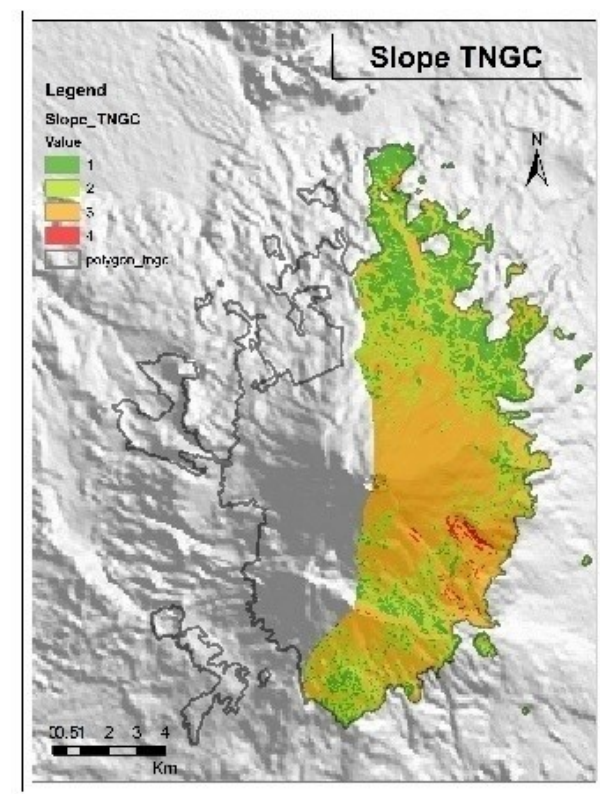

(a)

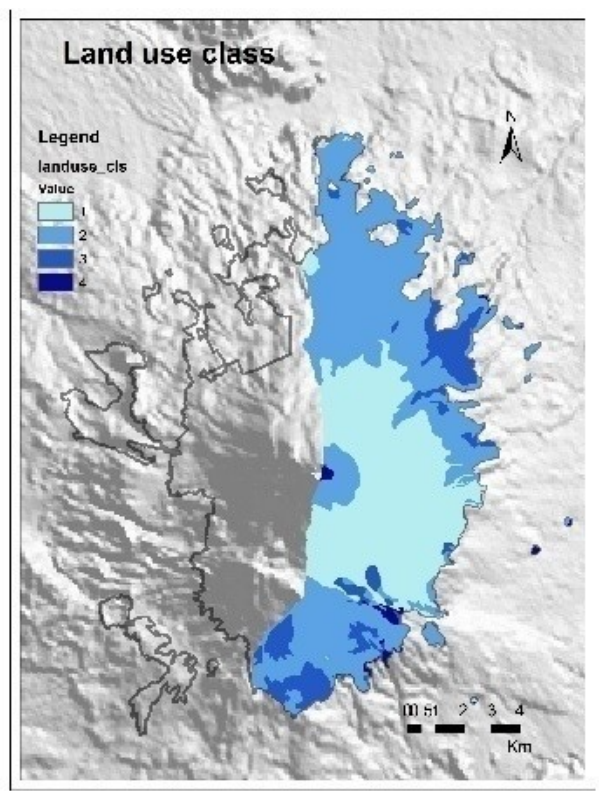

(b)

Fig. 1. Map of (a) Slope TNGC, (b) Land use class

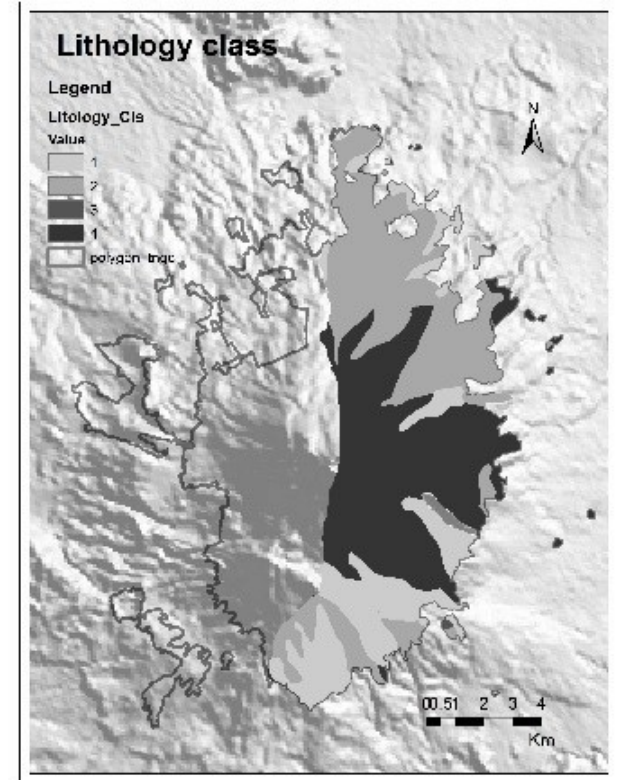

(a)

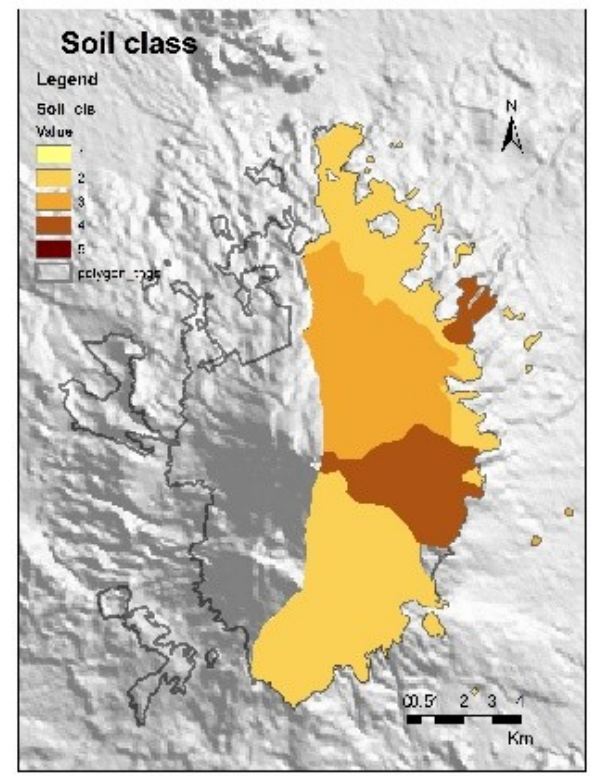

(b)

Fig. 2. Map of (a) Lithology class, (b) Soil class

\subsection{Soil Type}

The soil type is obtained from the map of the Puslittanak land system. Land class of vulnerability 1 is 3 hectare, class of vulnerability 2 is $4656 \mathrm{Ha}$, class of vulnerability of land 3 is $2528 \mathrm{Ha}$, and class of vulnerability 4 is $1517 \mathrm{Ha}$.

\subsection{Land Use}

The use is the result of processed land cover map from Balai TNGC. The result of land use land use map shows that land cover is 3305 Ha land-use prone class, $4479 \mathrm{Ha}$ of land use class 2, land use class 3 area of 925 $\mathrm{Ha}$ and 4 ha of land use class of $86 \mathrm{Ha}$.

\subsection{Map of Landslide Hazard TNGC}

In making the landslide susceptibility map, the four variables were processed with Raster Calculator (Spatial Analyze) tools with the formula $(40.8 *$ slope $)+(24.2 *$ lytology $)+(19,2 *$ ground $)+(15,8 *$ land use $)$ With the result shown in Figure 5 below. Very low vulnerability is $1882 \mathrm{Ha}$, low vulnerability $1980 \mathrm{Ha}$, vulnerability is $1356 \mathrm{Ha}$ high vulnerability $1308 \mathrm{Ha}$ and vulnerability very high $2001 \mathrm{Ha}$. 


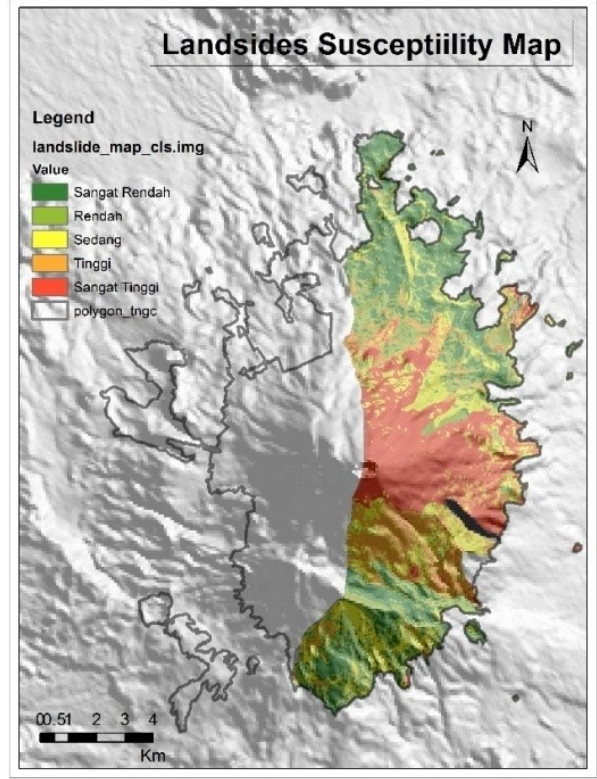

Fig. 2. Map of Landslides Susceptility

\section{Conclusion}

1. It can be said that susceptibility area spread on middle area of TNGC.

2. Elevation factor not so influential, but slope factor maybe more influents.

3. Area with highly susceptibility covering rehabilitation zone and utilization area.

\section{References}

1. Alamsjah, M. I. (2016) 'The Ministry of Tourism Exposure on KIDi 2016'. Yogyakarta.

2. Ioan, S. (2013) 'Ecological Tourism and Public Administration in Romania', Procedia - Social and Behavioral Sciences. 81, pp. 235-240.

3. Damanik, J. and Weber, H. F. (2006) Ecotourism Planning: from Theory to Practice. Yogyakarta: CV. Andi Offset.

4. Latupapua, Y. T. (2011) 'Public Perception of Potential Coastal Tourism Objects in Kei Kecil Subdistrict, Southeast Maluku District, Jurnal Agroforestri, 7(2), pp. 92-102.

5. Erfurt-cooper, P. (2015) 'Volcanoes and Tourism', in The Encyclopedia of Volcanoes. Second Edi.
Elsevier Inc., pp. 1295-1311.

6. PVMBG (2006) Introduction of Land Movements. Center for Volcanology and Geological Hazard Mitigation.

7. Lin, G., Chang, M., Huang, Y. and Ho, J. (2017) Engineering Geology. 224(September 2016), pp. 62-74.

8. Lukmantara, L. I. (2007). Scientific Contribution, 5(2), pp. 105-110.

9. Guillard, C. and Zezere, J. Environmental Management, 50(4), pp. 721-735.

10. Buchori, I. and Susilo, J. (2012). TATALOKA, 14(4), pp. 282-294.

11. Atmojo, S. W. (2008) 'The role of Agroforestry in Tackling Flood and Landslide', in Seminar Nasional Prndidikan Agroforestry Sebagai Strategi Menghadapi Pemanasan Global. Solo: Universitas Negeri Surakarta, pp. 1-15.

12. Fell, R., Corominas, J., Bonnard, C., Cascini, L., Leroi, E. and Savage, W. Z. (2008). Engineering Geology. 102(3-4), pp. 85-98.

13. Yalcin, A. (2008). CATENA, 72, pp. 1-12.

14. Feizizadeh, B. and Blaschke, T. (2011) Journal of Earth Science and Engeneering, 1(June 2017), pp. 66-71.

15. Leonardi, G., Palamara, R. and Cirianni, F. (2016) 'Landslide Susceptibility Mapping Using a Fuzzy Approach', Procedia Engineering. 161, pp. 380387.

16. Ercanoglu, M. (2008) 'An Overview on the Landslide Susceptibility Assessment Techniques', in The 1st WSEAS International Conference on Environmental and Geological and Engineering pp. 131-134.

17. Ayalew, L., Yamagishi, H., Marui, H. and Kanno, T. (2005) 'Landslides in Sado Island of Japan: Part II . GIS-based susceptibility mapping with comparisons of results from two methods and verifications', 81, pp. 432-445.

18. Sabokbar, H. F., Roodposhti, M. S. and Tazik, E. (2014) Geomorphology. 226, pp. 15-24.

19. Wati, S. E., Hastuti, T., Widjojo, S., Pinem, F. and Information, W. (2010) 'Landslides Susceptibility Mapping with Heuristic Approach in Mountainous Area a Case Study in Tawang Mangu Subsdistrict, Central Java, Indonesia', in International Archives of the Photogrammetry, Remote Sensing and Spatial Information Science. Kyoto, pp. 248-253. 